\title{
Quantitative analysis of axon collaterals of single pyramidal cells of the anterior piriform cortex of the guinea pig
}

\author{
Junli Yang ${ }^{1,2^{*}}$, Gerhard Litscher ${ }^{1,3^{*}}$, Z Zhongren Sun ${ }^{1 *}$, Qiang Tang ${ }^{1}$, Kiyoshi Kishi ${ }^{2}$, Satoko Oda ${ }^{2}$, \\ Masaaki Takayanagi ${ }^{2}$, Zemin Sheng ${ }^{1,4}$, Yang Liu' ${ }^{1}$, Wenhai Guo' ${ }^{1}$, Ting Zhang ${ }^{1}$, Lu Wang ${ }^{1,3}$, Ingrid Gaischek ${ }^{3}$, \\ Daniela Litscher ${ }^{3}$, Irmgard Th. Lippe ${ }^{5}$ and Masaru Kuroda ${ }^{2}$
}

\begin{abstract}
Background: The role of the piriform cortex (PC) in olfactory information processing remains largely unknown. The anterior part of the piriform cortex (APC) has been the focus of cortical-level studies of olfactory coding, and associative processes have attracted considerable attention as an important part in odor discrimination and olfactory information processing. Associational connections of pyramidal cells in the guinea pig APC were studied by direct visualization of axons stained and quantitatively analyzed by intracellular biocytin injection in vivo.

Results: The observations illustrated that axon collaterals of the individual cells were widely and spatially distributed within the PC, and sometimes also showed a long associational projection to the olfactory bulb (OB). The data showed that long associational axons were both rostrally and caudally directed throughout the PC, and the intrinsic associational fibers of pyramidal cells in the APC are omnidirectional connections in the PC. Within the PC, associational axons typically followed rather linear trajectories and irregular bouton distributions. Quantitative data of the axon collaterals of two pyramidal cells in the APC showed that the average length of axonal collaterals was $101 \mathrm{~mm}$, out of which $79 \mathrm{~mm}$ (78\% of total length) were distributed in the PC. The average number of boutons was 8926 and 7101 , respectively, with $79 \%$ of the total number of boutons being distributed in the PC. The percentage of the total area of the APC and the posterior piriform cortex occupied by the average distribution region of the axon collaterals of two superficial pyramidal (SP) cells was about 18 and 5\%, respectively.
\end{abstract}

Conclusion: Our results demonstrate that omnidirectional connection of pyramidal cells in the APC provides a substrate for recurrent processes. These findings indicate that the axon collaterals of SP cells in the PC could make synaptic contacts with all granule cells in the OB. This study provides the morphological evidence for understanding the mechanisms of information processing and associative memory in the APC.

Keywords: Anterior piriform cortex, Olfactory cortex, Olfactory bulb, Single neurons, Axon collaterals, Neural network

\section{Background}

The piriform cortex (PC) has long been treated as the "primary" olfactory cortex because of the largest area

\footnotetext{
*Correspondence: junli201601@126.com;

gerhard.litscher@medunigraz.at; szr006@163.com

${ }^{1}$ Second Affiliated Hospital of Heilongjiang University of Chinese Medicine, Harbin 150001, China

${ }^{3}$ Research Unit for Complementary and Integrative Laser Medicine, Research Unit of Biomedical Engineering in Anesthesia and Intensive Care Medicine, and TCM Research Center Graz, Medical University of Graz, 8036 Graz, Austria

Full list of author information is available at the end of the article
}

that receives direct input from the olfactory bulb (OB) [1, $2]$, the structure that monosynaptically relays input from olfactory neurons [3]. It is not homogeneous in structure although the entire PC has the same basic three-layer organization.

Many differences in both axonal connections and the cytoarchitecture of different regions of the PC have been described $[1,4-10]$. It is generally considered to consist of just two divisions though Rose [11] subdivided the rodent PC into multiple areas. The PC is divided into the anterior piriform cortex (APC) and the posterior 
piriform cortex (PPC) $[6,12,13]$. The most obvious difference between the APC and the PPC is that the lateral olfactory tract (lo) stops short of the PPC. APC and PPC also differ in the organization of intrinsic associational systems. Although cellular-level analysis will be required for confirmation, population-level morphological studies indicate that associational axons are both rostrally and caudally directed in the APC, and largely caudally directed in the PPC $[3,6,9,12,13]$. Physiological and modeling analysis has shown that the afferent activation of the APC is fast compared to the duration of postsynaptic potentials [14, 15]. A study from 2001 reported that the APC can be divided into dorsal $\left(\mathrm{APC}_{\mathrm{D}}\right)$ and ventral $\left(\mathrm{APC}_{\mathrm{V}}\right)$ subdivisions [10]. The PPC is situated posterior to the LOT and recognizable by a well-developed layer III, and the $\mathrm{APC}_{\mathrm{D}}$ is located dorsal to the LOT with a cytoarchitecture that is somewhat intermediate between that of the APCV and that of the PPC. These differences in structure are believed to reflect differences in functional roles $[10,16]$. The structure of the APC has led to the hypothesis that the PC functions as a distributed processing neural network and is critically involved in information processing and associative memory [17-19].

The current view of the odor discrimination suggests that the APC serves as a site of experience-induced enhancement in odorant discrimination, indicating convergence of odor information from many kinds of odor receptors into one PC neuron [20-29]. Studies by Wilson demonstrated that APC neurons discriminate alkane odorants based on carbon chain length [22, 23]. A mapping study of c-fos immunoreactivity in response to odorants suggested odor-specific spatial patterns of activity within the APC [30]. A result from optical imaging studies suggests that the dorsal part of the APC may be associated with odor concentration [31]. Therefore, in addition to recruitment of more olfactory sensory cells and glomeruli in response to stronger stimuli, a rostrocaudal gradient in axonal projections from mitral/tufted cells and/or in association fibers may play an important role in odor-concentration coding in the APC.

Studies using extracellularly-injected axon tracers have shown that associational axons are widely distributed spatially in the PC and extend into many adjacent cortical areas. However, these connections are not distributed at random; rather, there are broad, overlapping spatial patterns in both the origins and terminations of association axons $[6,9,12$, 13, 32]. An intracellular labeling study of pyramidal cells in layer IIb of the rat PPC showed cellular-level connectivity [3]. A surprise from this analysis is that individual layer II pyramidal cells in the PPC have extensively branching axons that are distributed to most of the highest-order behavior-related areas in the cerebral cortex. Previous studies also revealed the axonal branching patterns and bouton distribution of individual neurons in layers IIa, IIb, and III in the guinea pig PC [33-35]. These studies explored the organization of olfactory information processing in the APC, and investigated the validity of the current view of odor discrimination in the APC. In the present study using an intracellular injected axonal tracer, we will quantitatively analyze the distribution of axon collaterals on individual neurons in the APC, with special reference to the following points: (1) Analysis of the number of $P C$ neurons which make synaptic contacts with single APC neurons. Through this analysis, we can estimate the number of different kinds of odor receptors, which converge information into one APC neuron. (2) Analysis of the number of synapses of one APC neuron in the OB. By this analysis, we can estimate the magnitude of synaptic contacts between axon collaterals of APC neurons and granule cells of the OB. This study examines features of axon connections of superficial pyramidal (SP) cells that provide the morphological evidence for understanding the mechanisms of information processing and associative memory in the APC.

\section{Methods \\ Experimental procedures}

Animal procedures were approved by the Toho University Animal Care and Use Committee and conformed to the animal use guidelines of the National Institute of Health. Thirty-one male and female adult guinea pigs (800-1000 g/per animal) were anesthetized with intraperitoneal urethane injection (1 g urethane/kg body weight). Briefly, each animal was mounted on a stereotaxic instrument (Narishige, SN-3). Drainage of the cerebrospinal fluid at the atlantooccipital joint was routinely carried out to minimize pulsation of the brain. An opening in the dorsal cranium was made using a dental drill to introduce stimulating electrodes to the $\mathrm{OB}$. Another opening was made for recording electrodes in the middle and the anterior part of the PC. The exposed surfaces of the brains were covered with a mixture of warmed mineral oil and white vaseline to prevent cooling and drying of the brain. Body temperature was maintained at approximately $37{ }^{\circ} \mathrm{C}$ using a heating pad. Stimulating bipolar concentric electrodes were vertically inserted into the anterior part of the OB. A glass recording electrode filled with $0.5 \mathrm{M} \mathrm{KCI}$ and $4 \%$ biocytin (Sigma, St. Louis, $\mathrm{MO}$, USA) in $0.05 \mathrm{M}$ Tris buffer, $\mathrm{pH}$ 7.4, was vertical inserted into the PC from the dorsal surface of the neocortex. To identify the position of the microelectrode tips in the $\mathrm{PC}$, we monitored the field potential evoked by $\mathrm{OB}$ stimuli, whose $A_{1}$-peak wave reversed near the border between layers I and IIb [20,36-38]. Cells were impaled in an area between the reversal point of the field potential and a point $100 \mu \mathrm{m}$ deeper than the reversal point. The injection of biocytin was performed by passing 1-3 $\mathrm{nA}$ 
depolarizing pulses for $500 \mathrm{~ms}$ at a frequency of 1.0 c.p.s., for 10-35 min. After biocytin injection, the wound was sterilized and sutured (Additional file 1: Table 1).

\section{Histology}

6-12 h After the injection of biocytin, animals were perfused through the heart with $4 \%$ paraformaldehyde in $0.1 \mathrm{M}$ sodium phosphate buffer (PB), $\mathrm{pH}$ 7.4. The brain was excised, postfixed overnight, and cryoprotected in $20 \%$ sucrose in PB. Serial frozen sections were cut at $80 \mu \mathrm{m}$ thickness. Sections were incubated with avidinbiotin-peroxidase complex (ABC; Vector, Burlingame, CA, USA). Biocytin-labeled cells were stained by incubation with $0.035 \% 3-3^{\prime}$-diaminobenzidine (DAB, Sigma) solution, and $0.015 \% \mathrm{H}_{2} \mathrm{O}_{2}$ in $0.5 \mathrm{M}$ Tris buffer, $\mathrm{pH}$ 7.4. The sections were mounted on gelatin-coated slides, and counterstained with $0.05 \%$ thionin.

\section{Data analysis}

Analysis was confined to SP cells in the dorsal subdivision of the APC $[12,13,39]$. The soma and dendrites were traced and reconstructed in coronal planes using a Nomarski-type microscope (Olympus) equipped with a drawing tube using a $40 \times$ objective. Axons were reconstructed through serial coronal sections using 20,40 , and $100 \times$ objectives. The reconstructions were rotated and superimposed onto the illustrations of the brain surface. The lengths of the axonal segments of each area in each coronal section were measured using a pen-type map meter (Koizumi; accuracy of measurement, $\pm 1 \mathrm{~mm}$ ).

For the quantitative determination of axon length, shrinkage in depth was corrected on the basis of the original section thickness of $80 \mu \mathrm{m}$. However, shrinkage in other dimensions was not corrected because it was minimal due to the attachment of sections to slides before dehydration. Accordingly, final axonal length was estimated from the measured length and the $80 \mu \mathrm{m}$ section thickness. Interbouton intervals were measured in each area at $40 \times$ magnification. Boutons were identified using the criteria established in an electron microscopic analysis of intracellularly injected pyramidal cells in the opossum PC [40].

Brain areas were defined according to previous descriptions [36, 37, 41-43]. The boundaries of the PC layers were defined according to the description of Price [1] and Haberly and Price [2, 32].

Statistical significance was analyzed by the student $t$ test and Welch's $t$ test when populations differed. Photomicrographs were acquired digitally using an Olympus SZX 12 microscope fitted with an Olympus DP 50 camera using Viewfinder Lite software (version 1.0). Image quality was optimized by adjusting sharpness using Paintshop Pro 9 software (version 7.04: Jasc Software) (Additional file 2: Table 2).

\section{Results}

To explore the organization of olfactory information processing and investigate the validity of view of the odor discrimination in the APC by using an intracellular biocytin, we injected axonal tracer into SP cells in the APC of the guinea pig.

The PC is commonly separated into APC and PPC, as illustrated in Fig. 1.

SP cells have a pyramidal to ellipsoid soma. These cells exhibit a single apical dendrite whose branches extend to the superficial limit of the molecular layer, multiple basal dendrites, a high concentration of dendritic spines, and a deeply directed axon [6].

In this study, the total number of stained SP cells in the APC was fifteen; reconstructions and detailed analysis were performed on two of the cells that appeared to be representative of the population because of difficulties in serially reconstructing the extensively arborized axon collaterals that were $90-111 \mathrm{~mm}$ long. Because of difficulties in the serial reconstruction of the extensively arborized axon collaterals, two SP cells, located in the caudal portion of the APC, were reconstructed and quantitatively analyzed. Examples of a biocytinlabeled SP cell and its axon collaterals are shown in Fig. 2.

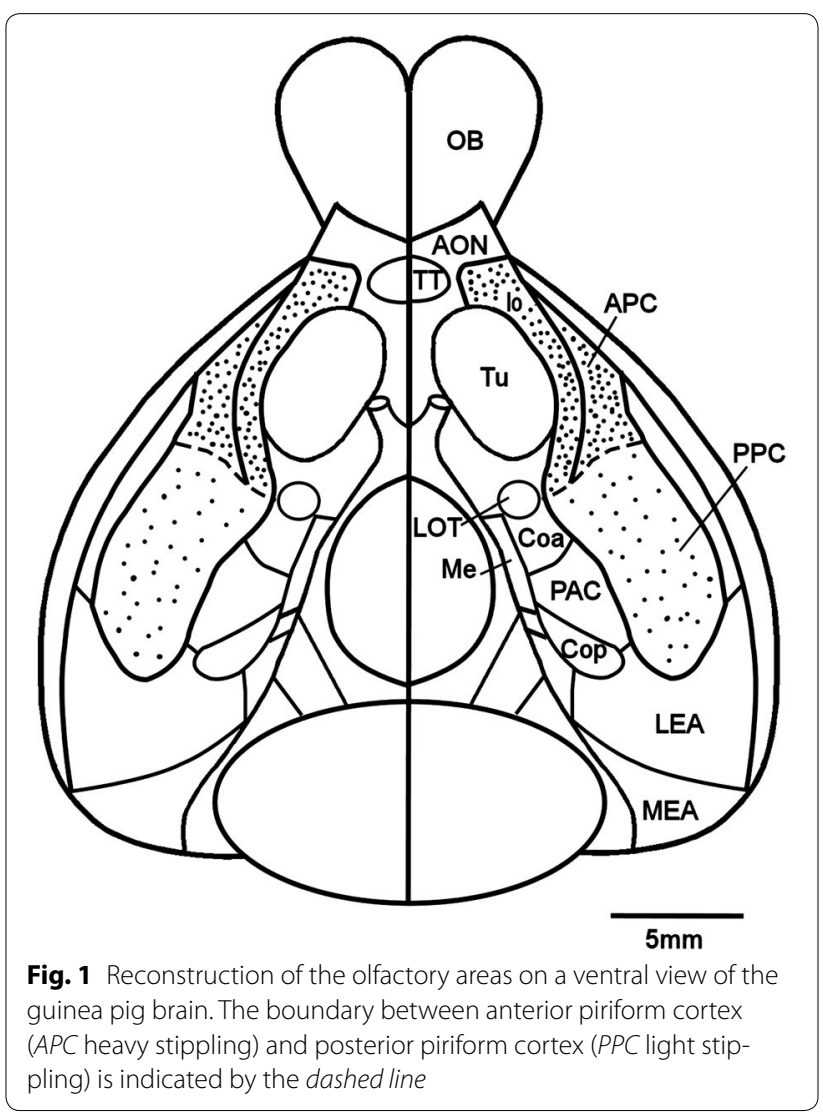




\section{Distribution of axon collaterals}

The SP cells had a pyramidal to ellipsoid soma, of which the long and short axes were $18.7 \pm 2.1$ and $12.1 \pm 0.8 \mu \mathrm{m}$ (mean $\pm \mathrm{SEM}, \mathrm{n}=2$ ). They exhibited a single apical dendrite the branches of which reached layer Ia and multiple basal dendrites. Both apical and basal dendrites were covered with a large number of small spines as shown in Fig. 3. The mean length of the dendritic spines of the two $\mathrm{SP}$ cells was $1.26 \pm 0.07 \mu \mathrm{m}$ (mean \pm SEM, $\mathrm{n}=104)$. The axon originated from the soma and projected 7-8 major collaterals. The lengths of axons from the soma to the end of branching points of major collaterals ranged from 255 to $335 \mu \mathrm{m}(280 \pm 55 \mu \mathrm{m}, \mathrm{n}=2)$.

The SP-1 cell shown in Fig. 4 was located in the APC, $2300 \mu \mathrm{m}$ rostral to the end of the lateral olfactory tract (lo). The axon collaterals of the SP-1 cell were reconstructed in coronal (Fig. 4a) and tangential planes (Fig. 4b). The axon projected 7 major collaterals to layer III. The axon from the soma to the end of the branching points of the major collaterals was $255 \mu \mathrm{m}$ long. The major axon collaterals followed relatively straight paths in layer III and gave rise to a small number of short branches and many extent arbors at irregular intervals. Then, some of the axon collaterals were oriented toward the superficial part of the PC, passing through layer IIb, and giving rise to horizontal branches in layer $\mathrm{Ib}$, a small number of which reached layer Ia. The arbors distributed within the PC were directed both rostrally and caudally, but were predominantly rostrally directed, as shown in Fig. 4b. The arbors in the PC were distributed over a wide area up to its medial border and laterally extended up to the rhinal fissure (RF). Outside the $\mathrm{PC}$, the axon collaterals were distributed in the dorsal endopiriform nucleus (DEn), olfactory tubercle $(\mathrm{Tu})$, agranular insular cortex (AI) and anterior olfactory nucleus (AON). In addition, one fairly thick collateral emanating from a major collateral in the deep part of layer III, reached rostrally in layer III adjacent to the DEn. Then, this thick collateral passed through the dorsal part of the AON, and reached the granular cell layer (GrL) of the OB.

The SP-2 cell, shown in Fig. 5, was located in the APC, $2100 \mu \mathrm{m}$ rostral to the anterior end of lo. The axon collaterals of the SP-2 cell were reconstructed in coronal

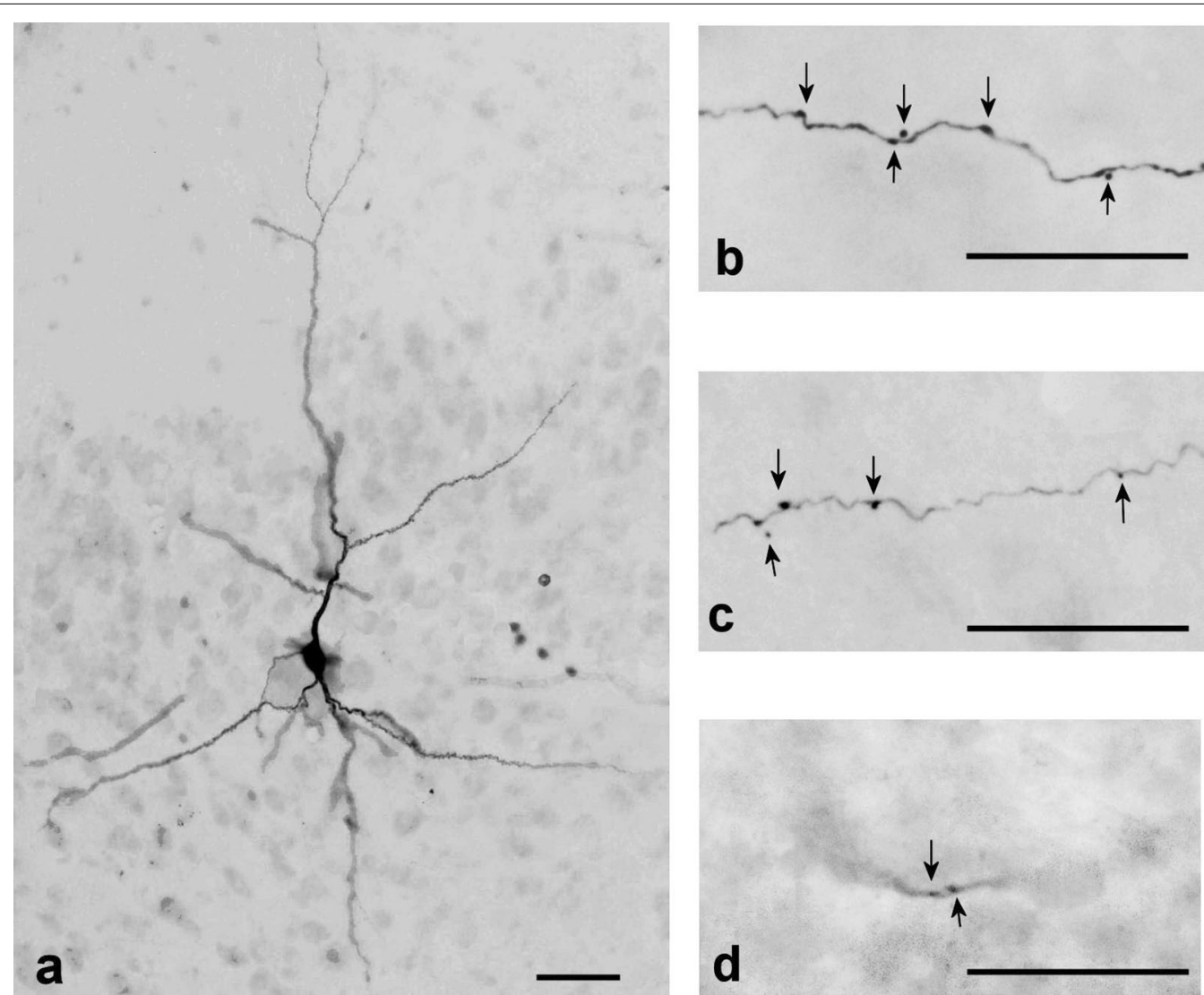

Fig. 2 Photomicrographs of coronal sections of the piriform cortex of the guinea pig. a Biocytin-injected superficial pyramidal cell in layer Ilbb. b-d Axon collateral of superficial pyramidal cell in layer III, AON and OB, respectively. Arrowheads indicate boutons. Scale bar $=50 \mu \mathrm{m}$ 


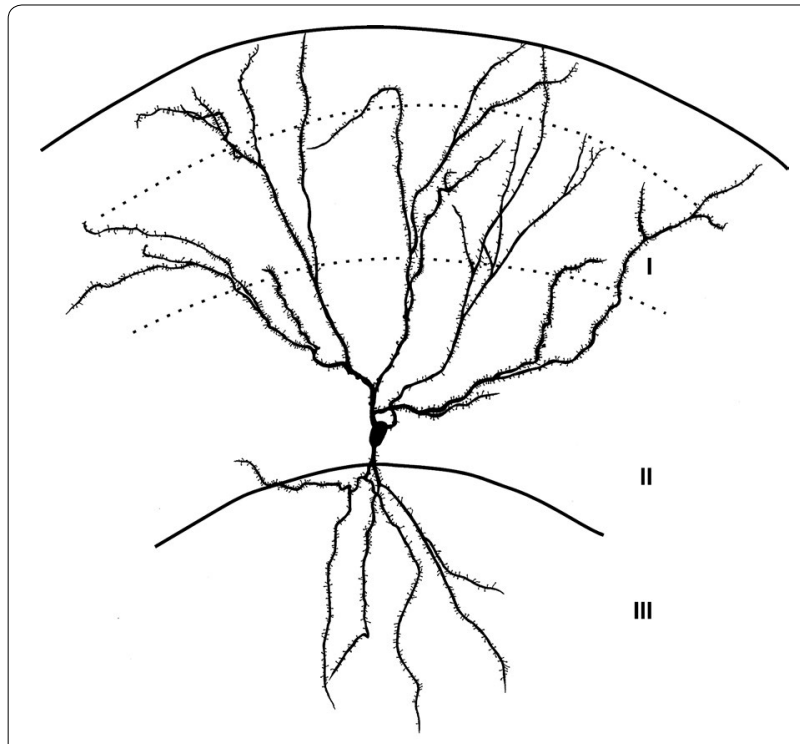

Fig. 3 Camera lucida illustration of soma and dendrites of a superficial pyramidal cell in the APC (SP-1 cell). Dendrites were reconstructed in a coronal plane. Solid lines indicate the surface of the brain and border between layers IIb and III, and dashed lines indicate the border between layers la and $\mathrm{lb}$ and the border between layers $\mathrm{Ib}$ and Ila. Note the large number of small spines on both the apical and basal dendrites. Scale bar $=50 \mu \mathrm{m}$

(Fig. 5a) and tangential planes (Fig. 5b). The axon projected 8 major collaterals to layer III. The axon from the soma to the end of the branching points of the major collaterals was $335 \mu \mathrm{m}$ long. The axon collaterals exhibited routes and distribution patterns largely similar to those of the SP-1 cell. In the tangential plane, the axons distributed within the PC were also directed rostro-caudally, but predominantly rostrally directed, as shown in Fig. 5b. Their collaterals were heavily distributed in the PC. Outside the PC, collaterals also projected to the DEn, Tu, AI and $\mathrm{AON}$. In addition, one fairly thick collateral emanating from a major collateral, took a similar course towards the GrL of the OB.

Table 1 shows the summary of quantitative data on the length of axon collaterals of reconstructed SP cells in the APC. The total length of axon collaterals of the two cells studied ranged from approximately $90-111 \mathrm{~mm}$, with an average length of $101 \mathrm{~mm}$. Axon collaterals with a length of $79 \mathrm{~mm}(78 \%)$ were distributed in the PC and those with a length of $21 \mathrm{~mm}(22 \%)$ in the areas outside the PC. Within the PC, 46-mm-long (57.8\%) axon collaterals were distributed in layer III, 9-mm-long axon collaterals $(12 \%)$ in layer II, 5-mm-long axon collaterals (7\%) in layer Ia, and 18-mm-long axon collaterals $(23.2 \%)$ in layer Ib.

Outside the PC, $5 \mathrm{~mm}$ (5.1\%) of the total axon length was distributed in the DEn, $7 \mathrm{~mm}(7 \%)$ in the Tu, $3 \mathrm{~mm}$ (3.1\%) in the AI, $6 \mathrm{~mm} \mathrm{(6.1 \% )} \mathrm{in} \mathrm{the} \mathrm{AON,} \mathrm{and} 0.4 \mathrm{~mm}$ $(0.4 \%)$ in the $\mathrm{OB}$.

\section{Distribution of boutons}

Table 2 shows the summary of the interbouton intervals and the number of boutons distributed in each area. Axon collaterals provided many boutons. More than $90 \%$ of the boutons were boutons en passant, and terminal boutons accounted for a small percentage in each area. The two SP cells did not differ significantly with regard to interbouton intervals in each layer of the PC. The mean interbouton intervals in each layer of the PC were not significantly different from each other. The mean interbouton interval in all layers of the PC was $10.7 \pm 0.2 \mu \mathrm{m}(\mathrm{n}=212)$. The interbouton intervals were $9.4 \pm 0.6 \mu \mathrm{m}$ (mean \pm SEM, $\mathrm{n}=14$ ) in layer Ia, $10.7 \pm 1.2 \mu \mathrm{m}(\mathrm{n}=67)$ in layer $\mathrm{Ib}, 11.1 \pm 1 \mu \mathrm{m}(\mathrm{n}=44)$ in layer II, and $11.5 \pm 1.3 \mu \mathrm{m}(\mathrm{n}=88)$ in layer III, which were not significantly different from each other. Outside of the $\mathrm{PC}$, the interbouton intervals in the DEn (13.1 $\pm 0.6 \mu \mathrm{m}, \mathrm{n}=28), \mathrm{Tu}(10.3 \pm 0.7 \mu \mathrm{m}, \mathrm{n}=21)$, AI $(12.1 \pm 0.8 \mu \mathrm{m}, \mathrm{n}=18)$ and AON $(14.2 \pm 1.2 \mu \mathrm{m}$, $\mathrm{n}=43$ ) were not significantly different from those in the PC. The interbouton interval in the $\mathrm{OB}(6.6 \pm 0.7 \mu \mathrm{m}$, $\mathrm{n}=7)$ was significantly shorter $(\mathrm{p}<0.05)$ than that in the PC.

The mean total number of boutons in a single SP cell of the APC was 8926 . The number of boutons distributed in the PC was 7101 (79.5\% of the total number of boutons), out of which 55.8, 24.1, 11.9 and 8.2\% were located in layers III, Ib, II, and Ia, respectively.

Outside the PC, the number of boutons was 1825 (20.5\% of the total number), out of which 391 were in the DEn, 685 in the Tu, 254 in the AI, 430 in the AON, and 65 in the OB (Additional file 3: Table 3).

(See figure on next page.)

Fig. 4 Coronal (a) and surface (b) views of reconstructed axon collaterals of a superficial pyramidal cell (SP-1 cell) located in the left hemisphere APC. a The position of the soma is indicated by a small dot, and that of the axon collaterals by thin solid or dashed lines. The Arabic numerals indicate the number of sections; the Roman numerals indicate the layer of the piriform cortex (PC). The solid lines indicate the axon collaterals distributed in the indicated areas within the represented sections as well as the adjacent sections. The dashed lines indicate collaterals running between these sections. Note that the axon collaterals are widely distributed within the PC and other olfactory areas and a long axon collateral projects to the granular cell layer of the olfactory bulb. b The small dot indicates the position of the soma. The collaterals (thin solid lines) extend to both rostral and caudal directions. The thick solid lines indicate the border between the areas of the cortical surface. The shaded area shows the lo. Scale bar $=1 \mathrm{~mm}$ 
a

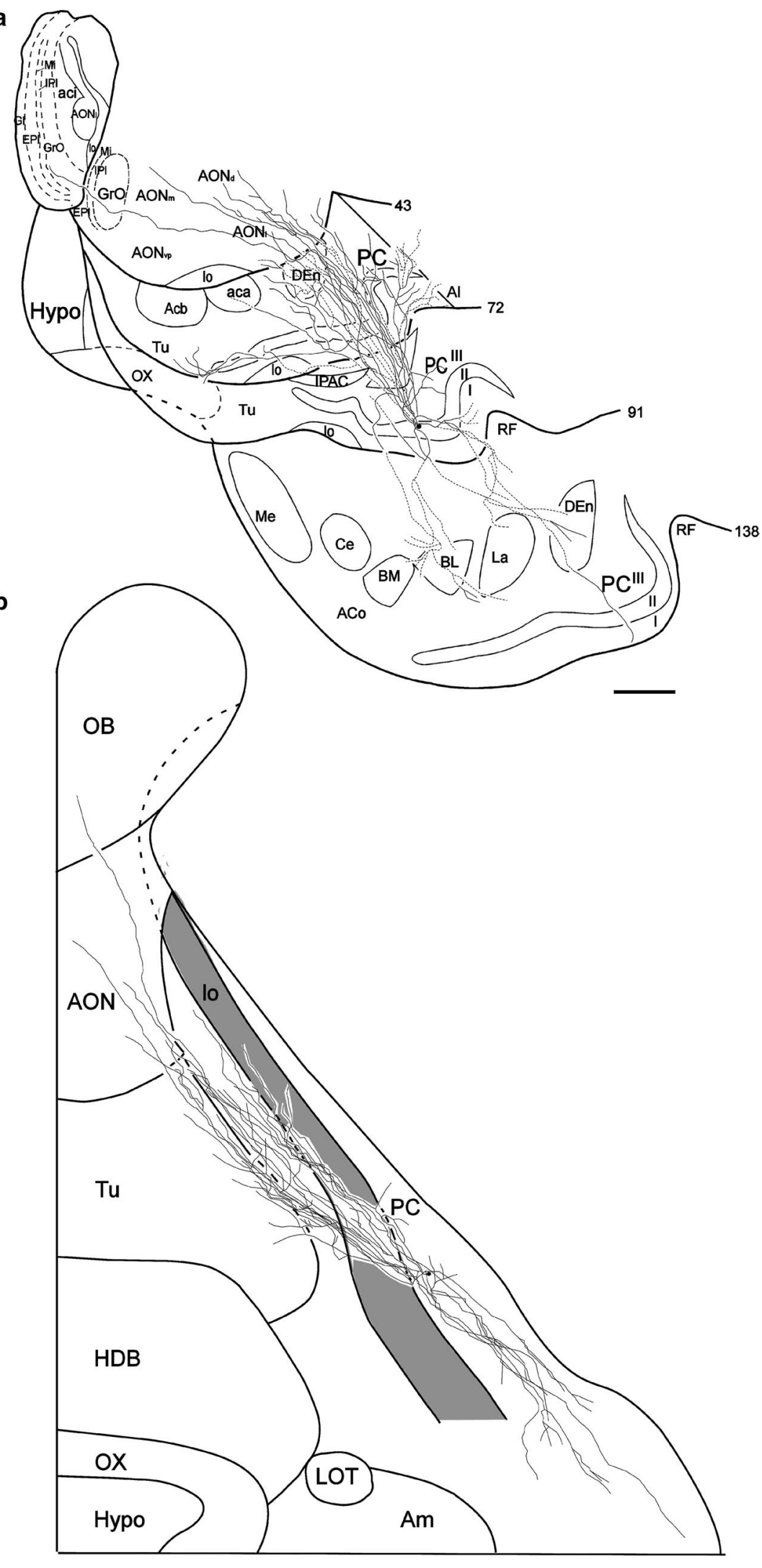


a

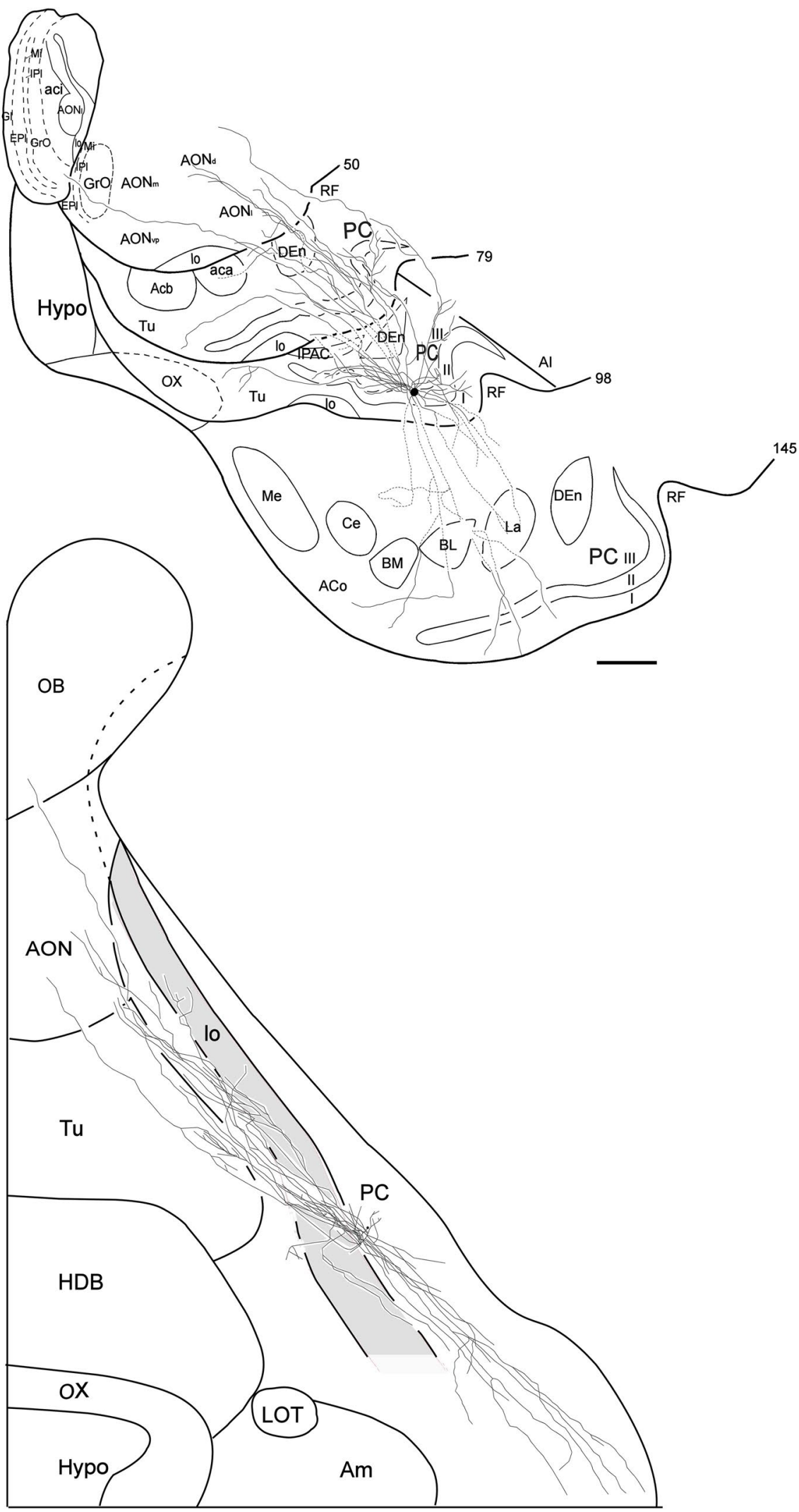


(See figure on previous page.)

Fig. 5 Coronal (a) and surface (b) views of reconstructed axon collaterals of a superficial pyramidal cell (SP-2 cell) located in the left hemisphere APC. Compared with the collaterals of the SP-1 cell (Fig. 4), the collaterals of this cell are very similar. $\mathbf{a}$ The axon collaterals are widely distributed within the PC and other olfactory areas and a long axon collateral projects to the olfactory bulb. $\mathbf{b}$ The small dot indicates the position of the soma. The collaterals extend in both rostral and caudal directions. The thick solid lines indicate the border between the areas of the cortical surface. Scale bar $=1 \mathrm{~mm}$

Table 1 Length $(\mu \mathrm{m})$ of axons of neurons in the layer Ilb of the APC

\begin{tabular}{|c|c|c|c|c|c|c|}
\hline \multirow[t]{2}{*}{ Area } & \multicolumn{4}{|c|}{ Length of axon } & \multicolumn{2}{|c|}{ Mean length of axon (mean \pm SEM) } \\
\hline & cell-1 & & cell-2 & & & \\
\hline Pir la & 6864 & $(6.2)$ & 4125 & $(4.6)$ & $5494 \pm 1370$ & $(5.5)$ \\
\hline Pir lb & 23,959 & $(22)$ & 12,624 & (14) & $18,292 \pm 5667$ & $(18.2)$ \\
\hline Pir II & 10,306 & $(9.3)$ & 8540 & $(9.5)$ & $9423 \pm 883$ & $(9.4)$ \\
\hline Pir III & 47,713 & $(43)$ & 43,365 & $(48)$ & $45,539 \pm 2174$ & $(45.3)$ \\
\hline PC total & 88,842 & $(80)$ & 68,654 & (76) & $78,748 \pm 32,641$ & $(78.3)$ \\
\hline DEn & 4003 & (3.6) & 6244 & $(6.9)$ & $5123 \pm 1121$ & $(5.1)$ \\
\hline Tu & 7207 & $(6.5)$ & 6897 & $(7.6)$ & $7052 \pm 155$ & $(7.0)$ \\
\hline $\mathrm{Al}$ & 3847 & $(3.5)$ & 2283 & $(2.5)$ & $3065 \pm 782$ & $(3.1)$ \\
\hline $\mathrm{AON}$ & 6147 & (5.6) & 6052 & $(6.7)$ & $6099 \pm 48$ & $(6.1)$ \\
\hline OB & 684 & $(0.6)$ & 174 & $(0.2)$ & $429 \pm 55$ & $(0.4)$ \\
\hline Total & 110,730 & $(100)$ & 90,303 & $(100)$ & $100,517 \pm 10,213$ & (100) \\
\hline
\end{tabular}

Values in parentheses indicate percentage of length of axons distributed in each area

Table 2 Number of boutons in neurons in layer Ilb of the APC

\begin{tabular}{|c|c|c|c|c|c|c|c|}
\hline \multirow[t]{2}{*}{ Area } & \multirow{2}{*}{$\begin{array}{l}\text { Interbouton intervals } \\
\text { (mean } \pm \text { SEM) }\end{array}$} & \multicolumn{4}{|c|}{ No. of boutons } & \multirow{2}{*}{$\begin{array}{l}\text { No. of boutons } \\
\text { (mean } \pm \text { SEM) }\end{array}$} & \multirow{2}{*}{$\begin{array}{l}\text { Percentage of boutons } \\
\text { en passant }\end{array}$} \\
\hline & & cell-1 & & cell-2 & & & \\
\hline PCla & $9.4 \pm 0.6$ & 730 & (7.4) & 439 & $(5.5)$ & $585 \pm 145.5$ & 91.3 \\
\hline PC Ib & $10.7 \pm 1.2$ & 2237 & (22.6) & 1180 & $(14.8)$ & $1708 \pm 528.6$ & 89.5 \\
\hline PC $\|$ & $11.1 \pm 1$ & 928 & $(9.4)$ & 769 & $(9.7)$ & $849 \pm 79.5$ & 93.9 \\
\hline PC III & $11.5 \pm 1.3$ & 4149 & $(41.9)$ & 3771 & $(47.5)$ & $3960 \pm 189$ & 93.3 \\
\hline PC total & $10.7 \pm 0.2$ & 8044 & $(81.2)$ & 6159 & (77.9) & $7101 \pm 942.6$ & 94.4 \\
\hline DEn & $13.1 \pm 0.6$ & 306 & (3.1) & 477 & (6) & $391 \pm 85.3$ & 95.9 \\
\hline Tu & $10.3 \pm 0.7$ & 700 & (7.1) & 670 & $(8.4)$ & $685 \pm 15.2$ & 94.4 \\
\hline $\mathrm{Al}$ & $12.1 \pm 0.8$ & 318 & (3.2) & 189 & $(2.4)$ & $254 \pm 64.5$ & 97.2 \\
\hline AON & $14.2 \pm 1.2$ & 433 & $(4.4)$ & 426 & $(5.4)$ & $430 \pm 3.5$ & 96.7 \\
\hline $\mathrm{OB}$ & $6.6 \pm 0.7$ & 104 & (1.1) & 26 & $(0.3)$ & $65 \pm 39$ & 100 \\
\hline Total & & 9905 & (100) & 7946 & $(100)$ & $8926 \pm 979.5$ & \\
\hline
\end{tabular}

Values in parentheses indicate percentage of number of boutons distributed in each area

Estimation of area where axon collaterals of a single SP cell are distributed

An important question for understanding the nature of information processing is the extent of the area where axon collaterals of single SP cells are distributed. As shown in Figs. 4b, 5b, the axon collaterals of each SP cell followed rather linear trajectories in two conical volumes, of which the apexes were located at the cell body of the SP cell. Assuming that linear trajectories of axon collaterals are randomly distributed in the conical volumes, the area occupied by axon collaterals of one SP cell can be estimated by the areas enclosed by a line interconnecting the outermost tips of each collaterals in the following four levels of the PC: A level of the APC approximately 1800$2200 \mu \mathrm{m}$ in depth (level 1 in Fig. 6a), a level of the APC approximately $4000-4400 \mu \mathrm{m}$ in depth (level 2), a level of the APC approximately 6200-6600 $\mu \mathrm{m}$ in depth (level 3 ), and a level of the PPC approximately 8400-8800 $\mu \mathrm{m}$ 
(level 4) from the anterior end of the PCs, the total length of which were $9300 \mu \mathrm{m}$ or $9700 \mu \mathrm{m}$ in the rostro-caudal direction. In each stack of sections, areas enclosed by a line interconnecting the proximal tips of collaterals and also by a line interconnecting the distal tips were estimated as two areas, where the axon collaterals of single SP cells were distributed (dotted and chain lines in Fig. 6b). The mean distribution areas of the axon collaterals of single SP cells occupied $17.3 \pm 4.1 \%$ of the APC area in level $1,28.7 \pm 11.7 \%$ in level 2 , and $8.6 \pm 1.0 \%$ in level 3 , the mean of which was $18.1 \pm 4.7 \%$ in the APC. The mean distribution area of the collaterals of single SP cells was $4.6 \pm 0.9 \%$ in level 4 in the PPC (Table 3).

\section{Discussion}

In this study we provided a complete visualization of the associational connections of single pyramidal cells from superficial layers II of APC in the guinea pig by intracellular biocytin injection and quantitative analysis of axon collaterals. The major findings of the present study are: (1) Axon collaterals from single SP cells in the APC are highly branched and widely spatially distributed within the PC and some higher order areas, especially they also showed a long associational projection to the OB. (2) The single SP cell in the APC gives rise to multiple, long association axons, and the long associational axons are both rostrally and caudally directed throughout the PC. Within the PC, associational axons typically followed rather linear trajectories and irregular bouton distributions. (3) The average number of boutons was 8926 , with $79 \%$ of the total number of boutons (7101) being distributed in the PC, and $0.7 \%(65)$ in the OB. (4) The average distribution region of the axon collaterals of the PC of two SP cells occupied about 18 and $5 \%$ of the total area of APC and PPC, respectively.

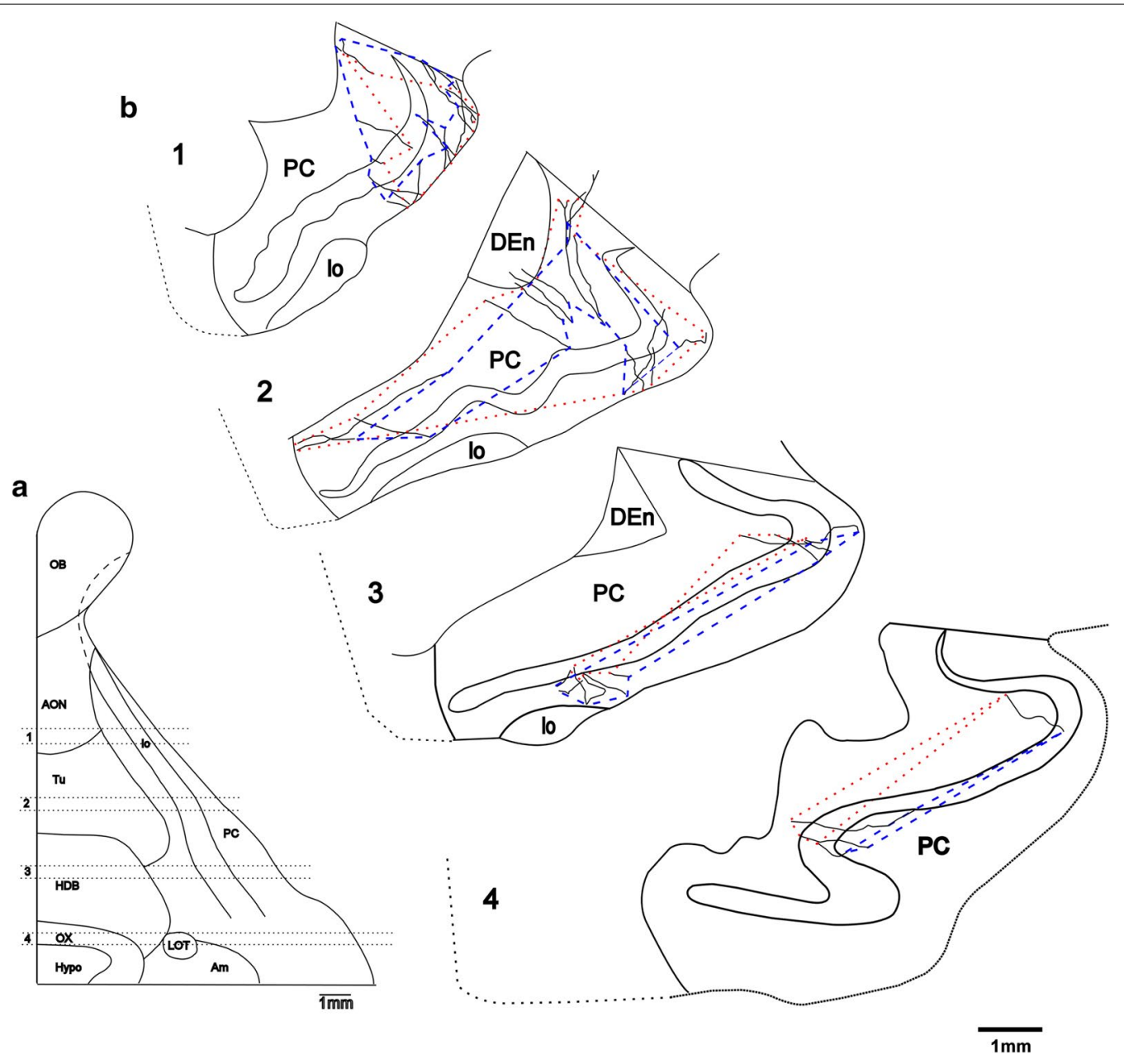

Fig. 6 Extent of area where axon collaterals of a single SP cell distribute. Levels 1-4 in the ventral brain surface (a) correspond to the four levels in the coronal plane reconstructed from 5 serial sections $(\mathbf{b})$. The axon collaterals of the SP-1 cell are distributed within areas interconnecting the outermost tips of proximal ends (dotted lines) and those of distal ends (chain lines) of the collaterals in each plane 
Table 3 Percentage of areas occupied by axon collaterals in the piriform cortex

\begin{tabular}{|c|c|c|c|c|c|c|}
\hline \multirow[t]{2}{*}{ Area } & \multirow[t]{2}{*}{ Level } & \multicolumn{2}{|l|}{ SP-1 } & \multicolumn{2}{|l|}{ SP-2 } & \multirow{2}{*}{$\begin{array}{l}\text { Mean } \pm \text { SEM } \\
\text { SP-1 and SP-2 }\end{array}$} \\
\hline & & Proximal & Distal & Proximal & distal & \\
\hline \multirow[t]{3}{*}{ APC } & 1 & 20 & 26 & 13 & 10 & $17.3 \pm 4.1$ \\
\hline & 2 & 57.8 & 32.5 & 13.5 & 10.6 & $28.7 \pm 11.7$ \\
\hline & 3 & 7.4 & 12.3 & 4.5 & 9.9 & $8.6 \pm 1$ \\
\hline Mean of APC & & 28.4 & 23.6 & 10.3 & 10.2 & $18.1 \pm 4.7$ \\
\hline PPC & 4 & 5.3 & 1.3 & 8 & 0.5 & $4.6 \pm 0.9$ \\
\hline
\end{tabular}

\section{New features of axon collaterals}

The SP cells in the APC in this study have highly spatially distributed axon collaterals in the PC. Previous studies with both extracellularly and intracellularly injected axonal tracers have revealed that the intrinsic associational projections of SP cells in the PC are highly distributed spatially $[6,9,12,13,32,38,44-46]$. Our results support those of the previous studies. A single SP cell in the APC gives rise to multiple, long association axons, passing throughout the PC. Studies with intracellular injection of SP cells in the PPC in rats [3] showed that axon collaterals are highly branched and distributed over an area that can encompass virtually an entire cerebral hemisphere. This was also shown in our report in the PC of guinea pigs [34]. The present observations showed that axon collaterals from single SP cells in the APC are highly branched and widely spatially distributed. A particularly intriguing feature is that axon collaterals from single SP cells in the APC are more highly distributed in the PC (78\% of the total length), and also arborized extensively in some higher order areas within the DEn, Tu and AON. The results are in agreement with those of Johnson et al. [3] and ul Quraish et al. [34] regarding extensive axonal distribution in the $\mathrm{PC}$ to the $\mathrm{SP}$ cells in the PPC of the rat and to the SP cells in the PC of the guinea pig, but differ in extensive axonal distribution outside the PC. Many studies have shown that long associational axons are both rostrally and caudally directed throughout the APC, and largely caudally directed in the PPC $[3,6,9,12,13]$. The studies using an extracellular injected axonal tracer showed the proportion of cells in layers II and III that gave rise to association fibers, and thus explained the predominance of rostrocaudal fibers over caudorostral ones. The results indicate a precise laminar organization of the PC in which the rostrocaudal fibers originate mainly from layer II and the caudorostral fibers primarily from layer III $[6,32]$. At the cellular level, our results support the finding that the APC and PPC differ in the organization of the intrinsic association system. The SP cells in the APC have both rostrally and caudally directed intrinsic association fibers. It is proposed that, as a result of this spatially distributed recurrent connectivity, the APC supports autoassociative processes [47]. The results of the present study are also consistent with those of Johnson et al. [3], because within the PC, associational axons typically followed linear trajectories, and regions of extensive branching were observed. Specifically, a long axon collateral projecting to the $\mathrm{GrL}$ of the $\mathrm{OB}$ was observed in the present study. Data reported on the basis of HRP retrograde transport experiments showed that the APC projects to the OB in the tree shrew [48], cat [49] and rat $[6,32]$. The examination of anterograde transport from HRP and amino acid injections into the PC indicate that this projection is to the $\mathrm{GrL}$ of the $\mathrm{OB}[6,32,50]$. Autoradiographic studies have revealed that neurons of both layer II and layer III in the PC in the hamster have centrifugal projections to the main $\mathrm{OB}[12,13,51-53]$. The finding that axon collaterals of single SP cells in the PPC of the rat are projections to the $\mathrm{OB}$ has been briefly described by Johnson et al. [3]. Our report confirmed these observations. Furthermore, in this study, this was analyzed quantitatively. Our study is the first to provide a visualization of the association axons projecting to the $\mathrm{GrL}$ of the $\mathrm{OB}$ from single SP cells of the APC in the guinea pig using intracellular biocytin techniques.

\section{Information processing in PC}

The APC and PPC exhibit many differences in terms of both axonal connections and cytoarchitecture $[6,9,10$, 32]. These differences in structure are believed to reflect differences in functional roles $[10,54]$. Despite the fact that the APC is the primary sensory cortex in the olfactory system, relatively little is known about the basic sensory processing of this structure. The structure of the APC has led to the hypothesis that the PC functions as a distributed processing neural network, and is critically involved in information processing and associative memory [17-19]. Considerable attention has been given to the spatial organization of cellular interconnections in the APC. We have demonstrated that individual SP cells in the APC have highly extensive axon collaterals. A 
particularly intriguing feature is that axon collaterals are widely distributed in the PC, and also arborized extensively in some higher order areas. A striking feature of the APC is its extensive intrinsic associational circuitry that is both rostrally and caudally directed over long distances. It is proposed that, as a result of this spatially distributed recurrent connectivity, the APC supports autoassociative processes [47].

The present study has revealed that the axon collaterals of individual SP cells are distributed in an area occupying approximately $18 \%$ of the APC, indicating that information activities from three to four different types of olfactory receptor converge onto individual SP cells in the APC. These anatomical features could facilitate the increase in the synaptic strength of the axon collaterals of SP cells by temporal convergence of co-occurring odor-features, generating the synthetic coding of familiar odors. The synthetic coding of odors as unique objects may increase the discrimination of similar objects as well as enhance recognition of those objects even if input is partially degraded [20-26, 28, 47].

In this study, the axon collaterals of SP cells in the APC projected to the GrL of the $\mathrm{OB}$, although the axon collaterals provided several collaterals reaching the AON. Several workers $[6,12,13,32,50,51]$ have reported that the PC projects to the GrL of the OB. The centrifugal projections to the $\mathrm{OB}$ originate predominantly in the APC and gradually decrease in number in the PPC. The intrabulbar axon collaterals of single SP cells have been briefly described by Johnson et al. [3]. However, the number of intrabulbar boutons of the collaterals of individual SP cells has not yet been determined. The present study has shown that SP cells in the APC have 26-104 boutons in the $\mathrm{GrL}$ of the OB. The number of granule cells in the $\mathrm{OB}$ ranges from $2.5 \times 10^{6}$ to $5 \times 10^{6}$ in the rat [54] and from $5 \times 10^{6}$ to $10 \times 10^{6}$ in the rabbit [55]. Assuming that half the population of SP cells in all regions of the PC projects to the $\mathrm{GrL}$ of the $\mathrm{OB}[6,32,53], 50 \%$ of the intrabulbar boutons of single SP cells form synaptic contacts with granule cells [40] and two boutons located within a short distance (approximately $6.6 \mu \mathrm{m}$ ) form synaptic contacts with one granule cell, the number of boutons required to drive all granule cells is $17-69$, which is roughly similar to the number of intrabulbar boutons determined in this study. The intrabulbar axon collaterals of the SP cells elicit monosynaptic EPSP in the granule cells, which in turn inhibits the activity of the mitral cells in the OB [5658]. The centrifugal fibers from the SP cells alter the form of oscillatory activity in the OB [59], the spatial amplitude patterns of which were suggested to be odor-specific [60].

Our study has of course also some limitations. We used only two neurons for reconstruction and analysis that appeared representative of the population. Addition of that data would bolster the applicability of the conclusions from the two fully reconstructed cells therefore we will gradually complete this work in the further studies.

\section{Conclusion}

The main results of our study show that omnidirectional connection of pyramidal cells in the anterior part of the piriform cortex (APC) provides a substrate for recurrent processes. It indicates that the axon collaterals of superficial pyramidal (SP) cells in the piriform cortex (PC) could make synaptic contacts with all granule cells in the olfactory bulb $(\mathrm{OB})$. This study provides the morphological evidence for understanding the mechanisms of information processing and associative memory in the APC.

\section{Additional files}

Additional file 1. Raw data for Table 1.

Additional file 2. Raw data for Table 2.

Additional file 3. Raw data for Table 3.

\section{Abbreviations}

aca: anterior commissure, anterior; aci: anterior comm, intrabulbar part; Acb: accumbens nucleus; Al: agranular insular cortex; Am: amygdaloid nuclear complex; $\mathrm{AON}$ : anterior olfactory nucleus; $\mathrm{AON}_{1}$ : anterior olfactory nucleus, pars lateralis; $\mathrm{AON}_{\mathrm{d}}$ : anterior olfactory nucleus, pars dorsalis; $\mathrm{AON}_{\mathrm{m}}$ : anterior olfactory nucleus, pars medialis; $\mathrm{AON}_{\mathrm{vp}}$ : anterior olfactory nucleus, pars ventroposterior; $A P C$ : anterior part of piriform cortex; $A P C_{D}$ : dorsal part of anterior piriform cortex; $\mathrm{APC}_{\mathrm{V}}$ : ventral part of anterior piriform cortex; BL: basolateral amygdaloid nucleus; BM: basomedial amygdaloid nucleus; Ce: central amygdaloid nucleus; DEn: dorsal endopiriform nucleus; EPI: external plexiform layer olfactory bulb; HDB: nucleus of horizontal limb diagonal band; Hypo: hypothalamus; IPAC: interstitial nucleus of posterior limb of anterior commissure; IPI: internal plexiform layer olfactory bulb; lo: lateral olfactory tract; Gl: glomerular layer of olfactory bulb; GrL: granular cell layer; GrO: granular cell layer of olfactory bulb; La: lateral amygdaloid nucleus; LOT: nucleus of lateral olfactory tract; Me: medial amygdaloid nucleus; OB: olfactory bulb; OX: optic chiasm; PC: piriform cortex; PPC: posterior part of piriform cortex; RF: rhinal fissure; SP: superficial pyramidal; Tu: olfactory tubercle.

\section{Authors' contributions}

JY conceived the study design, performed the data acquisition and analysis, drafted the article, and finally revised it critically for content. KK and MK contributed to the study design and experimental plan. SO and MT supported the experimental work and helped with the measurements. YL performed statistical data analysis. WG and TZ assisted in writing the article, e.g. by providing references. QT, GL, ZS, LW, IG, DL, IL and ZS revised the manuscript critically for content. All authors read and approved the final version of the manuscript.

\section{Author details \\ ${ }^{1}$ Second Affiliated Hospital of Heilongjiang University of Chinese Medicine, Harbin 150001, China. ${ }^{2}$ Department of Anatomy, School of Medicine, Toho University, Tokyo 143-8540, Japan. ${ }^{3}$ Research Unit for Complementary and Integrative Laser Medicine, Research Unit of Biomedical Engineering in Anesthesia and Intensive Care Medicine, and TCM Research Center Graz, Medical University of Graz, 8036 Graz, Austria. ${ }^{4}$ Privatclinic Lassnitzhoehe, 8301 Lassnitzhoehe, Austria. ${ }^{5}$ Institute of Experimental and Clinical Pharma- cology, Medical University of Graz, 8036 Graz, Austria.}

\section{Acknowledgements}

We thank Dr. Kimura A. for assistance with figures. 


\section{Competing interests}

The authors declare that they have no competing interests.

\section{Availability of data and materials}

The datasets supporting the conclusions of this article are included within the article and its additional files.

\section{Ethics approval}

Animal procedures were approved by the Toho University Animal Care and Use Committee and conformed to the animal use guidelines of the National Institute of Health.

\section{Funding}

Grant sponsor: Ministry of Education, Culture, Sports, Science, and Technology of Japan; Grant numbers: 0987817 and 14580776. The work in Austria was supported by the Austrian Federal Ministry of Science, Research and Economy.

Received: 28 April 2016 Accepted: 24 January 2017

Published online: 08 February 2017

\section{References}

1. Price JL. An autoradiographic study of complementary laminar patterns of termination of afferent fibers to the olfactory cortex. J Comp Neurol. 1973;150:87-108

2. Ojima H, Mori K, Kishi K. The trajectory of mitral cell axons in the rabbit olfactory cortex revealed by intracellular HRP injection. J Comp Neurol. 1984:230:77-87.

3. Johnson DMG, Illig KR, Behan M, Haberly LB. New features of connectivity in piriform cortex visualized by intracellular injection of pyramidal cells suggest that "primary" olfactory cortex functions like "association" cortex in other sensory systems. J Neurosci. 2000;20:6974-82.

4. Rose M. Die Inselrinde des Menschen und der Tiere. J Psychol Neurol. (Leipzig). 1928;37:467-624.

5. Haberly LB. Unitary analysis of opossum prepyriform cortex. J Neurophysiol. 1973:36(4):762-74.

6. Haberly LB, Price JL. Association and commissural fiber systems of the olfactory cortex of the rat. I. Systems originating in the piriform cortex and adjacent areas. J Comp Neurol. 1978;178:711-40.

7. Carmichael ST, Clugnet MC, Price JL. Central olfactory connections in the macaque monkey. J Comp Neurol. 1994:346:403-34.

8. Behan M, Johnson DMG, Feig SL, Haberly LB. A new anatomically and physiologically distinct subdivision of the piriform (olfactory) cortex. Soc Neurosci Abstr. 1995;21:1186.

9. Datiche F, Litaudon P, Cattarelli M. Intrinsic association fiber system of the piriform cortex: a quantitative study based on a cholera toxin B subunit tracing in the rat. J Comp Neurol. 1996:376:265-77.

10. Ekstrand JJ, Domroese ME, Johnson DMG, Feig SL, Knodel SM, Behan M, Haberly LB. A new subdivision of anterior piriform cortex and associated deep nucleus with novel features of interest for olfaction and epilepsy. J Comp Neurol. 2001;434:289-307.

11. Rose M. Cytoarchitektonischer Atlas der Großhirnrinde der Maus. J Psychol Neurol. 1929:40:1-51.

12. Luskin MB, Price JL. The topographic organization of associational fibers of the olfactory system in the rat, including centrifugal fibers to the olfactory bulb. J Comp Neurol. 1983;216:264-91.

13. Luskin MB, Price $J$. The laminar distribution of intracortical fibers originating in the olfactory cortex of the rat. J Comp Neurol. 1983;216:292-302.

14. Ketchum KL, Haberly LB. Membrane currents evoked by afferent fiber stimulation in rat piriform cortex. I. Current source-density analysis. J Neurophysiol. 1993;69:248-60.

15. Ketchum KL, Haberly LB. Membrane currents evoked by afferent fiber stimulation in rat piriform cortex. II. Analysis with a system model. J Neurophysiol. 1993;69:261-81.

16. Kaas JH. How sensory cortex is subdivided in mammals: implications for studies of prefrontal cortex. Prog Brain Res. 1990;85:3-11.
17. Haberly LB. Neuronal circuitry in olfactory cortex: anatomy and functional implications. Chem Senses. 1985;10:219-38.

18. Wilson MA, Bower JM. A computer simulation of olfactory cortex with functional implications for storage and retrieval of olfactory information. In: Anderson DZ, editor. Neural information processing systems. New York: American Institute of Physics; 1988. p. 114-26.

19. Lynch G, Granger R. Serial steps in mercury processing: possible clues from studies of plasticity in the olfactory-hippocampal circuit. In: Davis $J$, Eichenbaum $\mathrm{H}$, editors. Olfaction: a model system for computational neurosciences. Cambridge: MIT Press; 1991. p. 145-65.

20. Wilson DA. Habituation of odor responses in the rat anterior piriform cortex. J Neurophysiol. 1998;79:1425-40.

21. Wilson DA. Synaptic correlates of odor habituation in the rat anterior piriform cortex. J Neurophysiol. 1998;80:998-1001.

22. Wilson DA. Odor specificity of habituation in the rat anterior piriform cortex. J Neurophysiol. 2000;83:139-45.

23. Wilson DA. A comparison of odor receptive field plasticity in the rat olfactory bulb and anterior piriform cortex. J Neurophysiol. 2000;84:3036-42.

24. Wilson DA. Scopolamine enhances generalization between odor representations in rat olfactory cortex. Learn Mem. 2001:8:279-85.

25. Wilson DA. Receptive fields in the rat piriform cortex. Chem Senses. 2001:26:577-84.

26. Wilson DA. Rapid, experience-induced enhancement in odorant discrimination by anterior piriform cortex neurons. J Neurophysiol. 2003;90:65-72.

27. Wilson DA, Stevenson RJ. The fundamental role of memory in olfactory perception. Trends Neurosci. 2003;26(5):243-7.

28. Wilson DA. Odor perception is dynamic: consequences for interpretation of odor maps. Chem Senses. 2005:30:105-6.

29. Wilson DA, Best AR, Brunjes PC. Trans-neuronal modification of anterior piriform cortical circuitry in the rat. Brain Res. 2000;853:317-22.

30. Illig KR, Haberly LB. Odor-evoked activity is spatially distributed in piriform cortex. J Comp Neurol. 2003:457:361-73.

31. Sugal T, Miyazawa T, Fukuda M, Yoshimura H, Onoda N. Odor-concentration coding in the guinea-pig piriform cortex. Neuroscience. 2005;130:769-81.

32. Haberly LB, Price JL. Association and commissural fiber systems of the olfactory cortex of the rat. II. Systems originating in the olfactory peduncle. J Comp Neurol. 1978;181:781-807.

33. Yang JL, UI Quraish A, Murakami K, Ishikawa Y, Takayanagi M, Kakuta S, Kishi K. Quantitative analysis of axon collaterals of single neurons in layer lla of the piriform cortex of the guinea pig. J Comp Neurol. 2004:473:30-42.

34. UI Quraish A, Yang UL, Murakami K, Oda S, Takayanagi M, Kimura A, Kakuta S, Kishi K. Quantitative analysis of axon collateralls of single superficial pyramidal cells in layer Ilb of the piriform cortex of the guinea pig. Brain Res. 2004;1026:84-94.

35. Chen SY, Murakami K, Oda S, Kishi K. Quantitative analysis of axon collaterals of single cells in layer III of the piriform cortex of the guinea pig. J Comp Neurol. 2003:465:455-65.

36. Paxinos $G$, Watson C. The rat brain in stereotaxic coordinates. Sydney: Academic Press; 1986

37. Shipley MT, McLean JH, Ennis M. Olfactory system. In: Paxinos G, editor. The rat nervous system. San Diego: Academic Press; 1995. p. 899-921.

38. Krettek JE, Price JL. Projections from the amygdaloid complex to the cerebral cortex and thalamus in the rat and cat. J Comp Neurol. 1977;172:687-722

39. Neville KR, Haberly LB. Beta and gamma oscillations in the olfactory sys tem of the urethane-anesthetized rat. J Neurophysiol. 2003:90:3921-30

40. Haberly LB, Presto S. Ultrastructural analysis of synaptic relationships of intracellularly stained pyramidal cell axons in piriform cortex. J Comp Neurol. 1986:248:464-74

41. Wree A, Zilles K, Schleicher A. A quantitative approach to cytoarchitectonics. VII. The areal pattern of the cortex of the guinea pig. Anat Embryol. 1981;162:81-103.

42. Alheid GF, de Olmos JS, Beltramino CA. Amygdala and extended amygdala. In: Paxinos G, editor. The rat nervous system. San Diego: Academic Press; 1995. p. 495-578.

43. Amaral DG, Witter MP. Hippocampal formation. In: Paxinos G, editor. The rat nervous system. San Diego: Academic Press; 1995. p. 443-94. 
44. Krettek JE, Price JL. Projections from the amygdaloid complex and adjacent olfactory structures to the entorhinal cortex and to the subiculum in the rat and cat. J Comp Neurol. 1977;172:723-52.

45. Krettek JE, Price JL. A description of the amygdaloid complex in the rat and cat, with observations on intra-amygdaloid axonal connections. J Comp Neurol. 1978;178:255-80.

46. Haberly LB, Bower JM. Analysis of association fiber system in piriform cortex with intracellular recording and staining methods. J Neurophysiol. 1984:5:90-112.

47. Haberly LB. Parallel-distributed processing in olfactory cortex: new insights from morphological and physiological analysis of neuronal circuitry. Chem Senses. 2001;26:551-76.

48. Skeen LC, Hall WC. Efferent projections of the main and accessory olfactory bulb in the tree shrew (Tupaia glis). J Comp Neurol. 1977;172:1-36.

49. Dennis BJ, Kerr DLB. Origins of olfactory bulb centrifugal fibres in the cat. Brain Res. 1976:110:593-600

50. de Olmos J, Hardy H, Heimer L. The afferent connection of the main and the accessory olfactory bulb formations in the rat: an experimental HRPstudy. J Comp Neurol. 1978;181:213-44.

51. Davis BJ, Macrides F, Youngs WM, Schneider SP, Rosene DL. Efferents and centrifugal afferents of the main and accessory olfactory bulbs in the hamster. Brain Res Bull. 1978:3:59-72.

52. Macrides F, Davis BJ, Youngs WM, Nadi NS, Margolis FL. Cholinergic and catecholaminergic afferents to the olfactory bulb in the hamster: a neuroanatomical, biochemical and histochemical investigation. J Comp Neurol. 1981;203:407-516.
53. Davis BJ, Macrides F. The organization of centrifugal projections from the anterior olfactory nucleus, ventral hippocampal rudiment and piriform cortex to the main olfactory bulb in the hamster: an autoradiographic study. J Comp Neurol. 1981;203:475-93.

54. Shepherd GM, Chen WR, Greer CA. The synaptic organization of the brain. New York: Oxford University Press; 2004. p. 165-216.

55. Shepherd GM. Synaptic organization of the mammalian olfactory bulb. Physiol Rev. 1972;52:864-917.

56. Nakashima M, Mori K, Takagi SF. Centrifugal influences on olfactory bulb activity in the rabbit. Brain Res. 1978;154:301-16.

57. Mori K, Takagi SF. An intracellular study of dendrodendritic inhibitory synapses on mitral cells in the rabbit olfactory bulb. J Physiol Lond. 1978:279:569-88.

58. Mori K, Takagi SF. Activation and inhibition of olfactory bulb neurons by anterior commissure volleys in the rabbit. J Physiol Lond. 1978:279:589-604.

59. Gray CM, Skinner JE. Centrifugal regulation of neuronal activity in the olfactory bulb of the waking rabbit as revealed by reversible cryogenic blockade. Exp Brain Res. 1988;69:378-86.

60. Freeman WJ, Schneider W. Changes in spatial patterns of rabbit olfactory EEG with conditioning to odors. Psychophysiology. 1982;19:44-56.

\section{Submit your next manuscript to BioMed Central and we will help you at every step:}

- We accept pre-submission inquiries

- Our selector tool helps you to find the most relevant journal

- We provide round the clock customer support

- Convenient online submission

- Thorough peer review

- Inclusion in PubMed and all major indexing services

- Maximum visibility for your research

Submit your manuscript at www.biomedcentral.com/submit 